\title{
A viewpoint: Rangeland health and mule deer habitat
}

\author{
CHARLIE D. CLEMENTS AND JAMES A. YOUNG
}

The authors are wildlife research assistant and research leader, USDA, Agr. Res. Serv., 920 Valley Road, Reno, Nev. 89512.

\begin{abstract}
The Lassen interstate mule deer (Odocoileus hemionus) herd ranges from the northwestern area of Nevada to the northeastern corner of California along the western rim of the Great Basin. This mule deer herd serves as a model for what has happened in terms of population dynamics for many Intermountain west mule deer populations. Before contact with Europeans the populations were apparently very restricted. After the introduction of domestic livestock there has been significant impacts on the relative abundance of shrubs versus perennial grasses. Mule deer herds underwent tremendous expansion which peaked in the 1950s. Recent mule deer population numbers in the Lassen interstate herd have sharply declined. These population dynamics can be related to several habitat changes that reflect increased frequencies of wildfires in lower elevational sites as shrubs became old and decadent. Lack of fire in the higher elevations resulted in decadent/senscent old shrub stands. Invasion by exotic annual grasses in lower elevational sites. In certain environments, sharply improved range condition due to grazing management systems. The increase in coniferous woodlands, which may reflect changes in climate and/or atmospheric gases, combined with the lack of fire significantly negatively impact the Lassen Interstate mule deer herd. Identifying the specific aspect of winter, transitional, and/or summer habitat, in terms of dietary deficiency, that are most closely related to the decline in mule deer numbers is a highly significant problem facing wildlife and range managers.
\end{abstract}

Key Words: Odocoileus hemionus, Purshia tridentata, bunchgrass, wildfire, historical perspective, Artemisia tridentata

Controversy exists over the issue of mule deer ranges. Wildlife managers, range managers, and other interested and involved parties often sit down and discuss the problems concerning mule deer habitat, resulting in much finger pointing and little problem solving. This controversy exists throughout the west, and such is the case over the East Lassen mule deer herd in northeastern California and northwestern Nevada. The main issue in this area involves the condition of antelope bitterbrush (Purshia tridentata (Pursh) DC.). Antelope bitterbrush is well documented as a critical browse species for wintering mule deer herds (Hormay 1943, Nord 1965). Many existing stands have no seedling recruitment, and are becoming decadent with low forage production. The

Manuscript accepted 27 Apr. 1996. twigs and winter persistent leaves of antelope bitterbrush are highly preferred by domestic livestock during late summer, fall, and winter months when herbaceous species are mature and low in digestible protein (Nord 1965).

As all involved parties (representatives from different Bureau of Land Management [BLM], USDI districts; Forest Service, USDA; California Fish and Game, Nevada Division of Wildlife, livestock permitees, and interested conservation groups) sit at the bargaining table it is apparent that adversary positions are immediately taken. These conversations often begin with game managers expressing the view that livestock grazing is causing much of the problems concerning mule deer habitat. This instantly places the stockmen on the defensive, thus the arguing begins and progress ends. This gridlock solves absolutely nothing.

This analysis provides current and historical background of mule deer population densities, vegetational changes, and the cyclic processes of eruption and decline of mule deer populations in northeastern California and northwestern Nevada (Fig. 1).

\section{Historical Perspective}

To understand the current conditions of mule deer herds in northeastern California and northwestern Nevada, we must first obtain a historical perspective on mule deer populations at the time of first contact with Europeans and the subsequent effect of settlement upon these populations.

Jedidiah Smith, Peter Skene Ogden, and John Work journeyed through the Great Basin during the second and third decades of the 19 th century. Their journals indicate that few mule deer were encountered. Despite these mountain men being the epitome of professional hunters, they often found themselves hungry and sometimes killed their own horses to survive (Helfrich et al. 1984, Work 1833, Leopold 1950). John Work described November 1832 near Alturas, Calif., "few tracks, but no site of deer". "Crossing the road was a singular barrier, built by Indians, to pen in, probably, large hares when they hunt them, for there is no other game here" reported Bruff on 25 September 1849 while traveling near Soldiers Meadows in northwestern Nevada (Helfrich et al. 1984). These early explorers and trappers noted the abundance of pronghorn (Antilocarpa americana), bighorn sheep (Ovis californica), and waterfowl, but also noted the scarcity of deer through their travels. The forested edges of the Great Basin provided good browse species for mule deer. The east slope of the northern Sierra Nevada in Honey Lake Valley in northeastern California is an example of such locations. In the early 1850 s, Honey Lake Valley was described as having plentiful deer, pronghorn, sagegrouse 


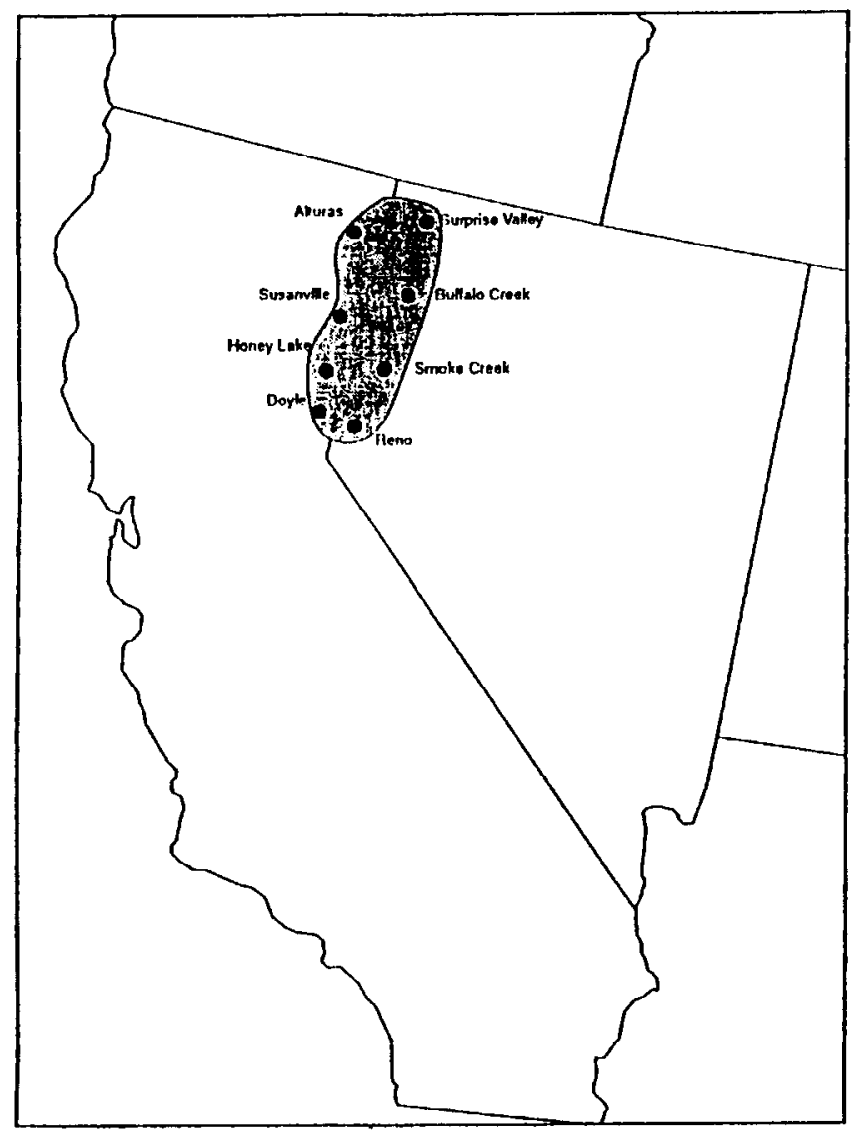

Fig. 1 Referred Interstate mule deer populations of northeastern California and northwestern Nevada.

(Centrocercus urophasianus), waterfowl, and rabbits (Lepus spp.). Black bear (Ursus americanus), mountain lions (Felis concolor), and bighorn sheep were in abundance (Anon. 1993). These early records are not sufficiently detailed to provide estimates of the numbers per species, but rather provide a snapshot back in time.

The areas where these early explorers and trappers traveled and recorded the scarcity of mule deer supported mule deer by the thousands a century later (Leopold et al. 1947, Leopold 1950, Julander 1955, Julander and Low 1976, Gruell 1986). Now, a half a century later, we are experiencing declining mule deer herds (Julander and Low 1976, Denny 1976, Loft and Menke 1990).

Mule deer are browsers and therefore benefit when shrub species such as antelope bitterbrush, preferred sagebrush (Artemisia) species and forms, curlleaf mountain mahogany (Cercocarpus ledifolius Nutt.), and other woody specics are productive components of their ranges (Dietz and Nagy 1976). These woody species are beneficial as they provide desired nutrition and cover (Leckenby et al. 1982). This does not exclude the nutritional importance of forbs and early growth grasses to the well being of mule deer (Austin and Urness 1985). Diet studies conducted in northeastern California indicate that forbs and grasses make up a large part of the mule deer diet in the early summer months (Leach 1956, Bissell and Strong 1955, Lassen et al. 1952), providing sufficient protein and phosphorus that is lacking after the dormant winter months (Dietz and Nagy 1976).
Most authorities agree that at the time of European contact, much of the prime mule deer ranges present during the early and mid 20th century did not exist (Julander and Low 1976, Gruell 1986). This supports the scarcity of mule deer noted by early explorers. Herbaceous vegetation apparently was a more significant portion of the environment under pre-contact conditions than woody species, indicating a lack of browse species (Clements and Clements 1939, Gruell 1986). The changes in plant communities that favored eruptions of mule deer populations are both subtle and overt, but are not easily understood.

\section{Historical Mule Deer Densities}

As previously noted, mule deer densities were very scarce in the Great Basin during the pre-contact period. Starting with the Comstock Lode, silver mining spread across the Great Basin with a series of boomtowns. These boom and often bust cycles of local development extended into the 20th century with Goldfield and Tonopah, Nev. These sudden spurts of population growth brought hunting pressure to isolated mule deer populations. During the same time period an extended network of ranches developed across the state. It was common for ranches with thousands of cattle on the range to use venison as a staple meat. Mule deer had smaller carcasses than cattle in the age of no refrigeration, and in the eyes of the consumer they were free. By the 1880 s the native wapiti (Cerves elaphus) of eastern Nevada were extinct (personal communication Mathis 1995, information officer, Nevada Division of Wildlife, retired). In the early 1900 s, it was front page news to have killed a mule deer near Reno, Nev. Laws to protect mule deer were virtually non-existent. From the first territorial Legislative Session in 1861 to the end of the century laws related to the harvest of mule deer consisted of no limit, long seasons, and no enforcement. With the coming of the 20th Century came the awareness for the need to protect our mule deer herds. In 1901 the Nevada Legislature closed the season for mule deer hunting until 1903, after which the limit was 2 male mule deer per person in a season that extended from 1 September to 1 November. By 1915 the limit was 1 per person with does legal, but fawns protected. In 1929, deer tags were established allowing 1 tag per person for $\$ 1$, although you could purchase a tag in each county (personal communication McQuivey 1995, chief of habitat, Nevada Division of Wildlife). Game refuges were also established. An entire section of the Lassen interstate mule deer herd habitat from the Skedaddle Mountain rim to Shinn Peaks was a game refuge from the mid 1910s through 1954 (personal communication Hall, field biologist, California Department of Fish and Game).

Estimates of mule deer populations were very crude at best until the late 1970 s when game agencies developed more precise methods of counting their leer herds. Even the early methods of observing mule deer numbers are useful in estimating and comparing densities. An example of this is the effort that sportsmen made during the $1950 \mathrm{~s}$ in counting the mule deer that migrated into an area called the Sand Hills, north of Reno, Nev. These individuals would ride horseback in this country on a weekend, and using a method of only counting mule deer that broke to their left, would count some 3,000 individual deer (personal communication Mathis 1995, information officer, Nevada Division of Wildlife, retired). Today, whether on horseback or in a helicopter, you would be fortunate to count 150 mule deer in the same area (personal communication Dobel 1995, field biologist, Nevada Division of Wildlife). It is obvious that the mule deer density is 
lower on this winter range at present time than it was 40 years ago. Loft and Menke (1990) reported that mule deer numbers in northeastern California and northwestern Nevada declined some 50\% from 1964 to 1988 (Fig. 2a). Many mule deer herds have declined to the lowest numbers ever recorded. The Independence mule deer herd in northeastern Nevada is an example of another mule deer herd that has declined to record low numbers, as indicated in their harvest data (Fig. 2b). The Nevada Division of Wildlife estimates that there were $32,000-38,000$ mule deer present in the Independence herd in the late $1950 \mathrm{~s}$ and early $1960 \mathrm{~s}$, compared to the estimated 10,000-14,000 currently present (personal communication Grey 1995, field biologist, Nevada Division of Wildlife). Loft and Menke (1990) suggests that deer herds in northeastern California and northwestern Nevada are on the decline due to unsuitable winter range conditions caused by the loss of browse plants to fire and overgrazing.

\section{Hypothesis for Mule Deer Population Eruptions}

Among alternatives to the absolute grassland versus shrubland hypothesis (Clements and Clements 1939, Gruell 1986) are: 1) the keystone changes in mule deer habitat are site specific and specific to the seasonal dietary requirements of mule deer, 2) the frequency and abundance of mule deer preferred sagebrush increased as a result of the environmental changes induced by livestock grazing, 3) changes occurred in the abundance of preferred shrubs in the rose family (Rosaceae, i. e. antelope bitterbrush) versus sunflower family (Asteraceae, i. e. sagebrush and rabbitbrush [Chrysothamnus]), 4) range improvement practices designed to increase perennial grasses negatively interacted with mule deer populations, 5) short term climatic and/or atmospheric changes influenced woodland vegetation, and 6) all of the above occurred and interacted along with the population genetics of the mule deer herds themselves.

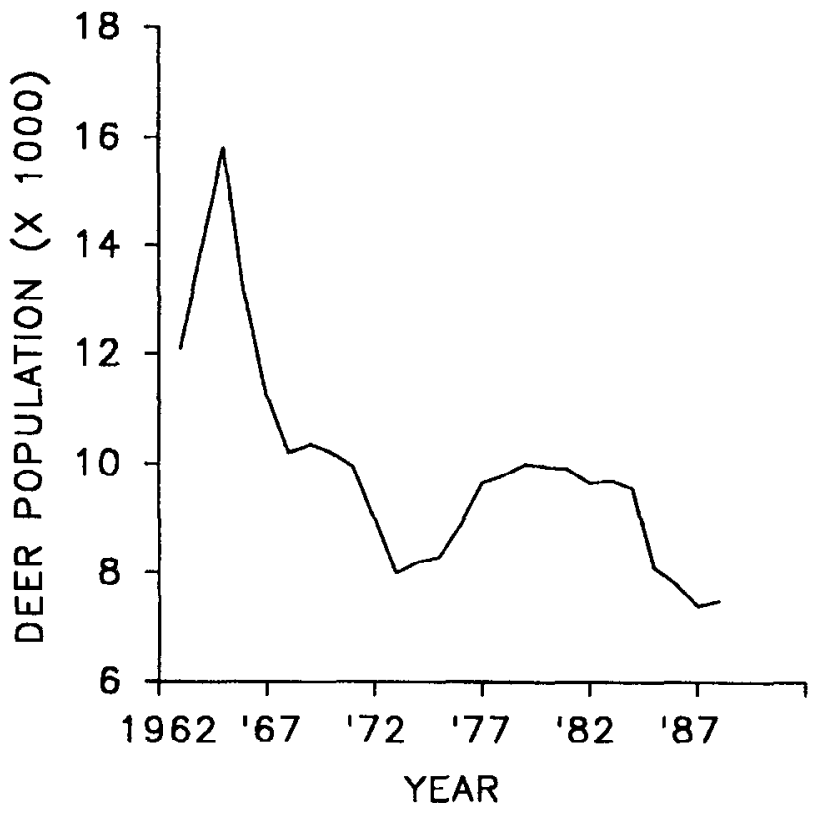

Fig. 2a. Mule deer population estimates for the East Lassen mule deer herd from 1962 to 1988 (Updike et al. 1990).

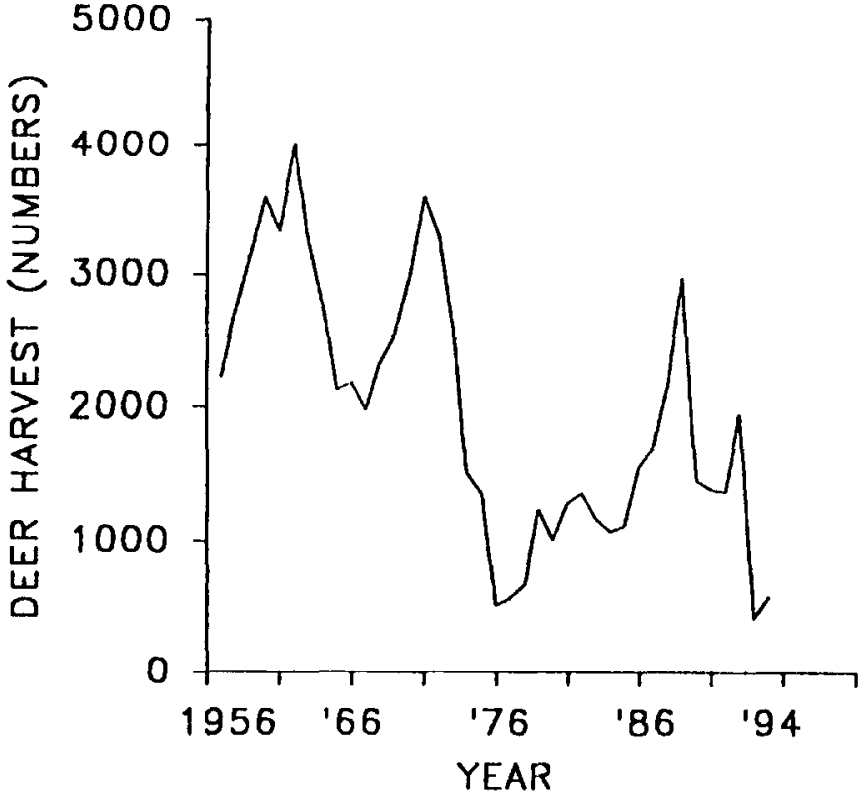

Fig. 2b. Harvest records for the Independence mule deer herd of northeastern Nevada from 1956 to 1994 (Grey personal communications).

Traditional mule deer habitat is separated into winter, transitional (spring-fall), and summer ranges. Often winter ranges have been considered the most critical areas for herd survival. In the western Great Basin the general aridity caused by Sierra-Cascade rain shadow raises vegetation zonation (Billings 1949), therefore summer ranges may be the limiting environment for herd productivity (Austin and Urness 1985). Transitional ranges in this region, apparently have not received the attention from habitat managers that has been devoted to winter ranges. With recognition that ecologically significant variations in big sagebrush populations below the species level (Beetle 1960, McArthur and Plummer 1978), it is readily apparent there are differences in big sagebrush populations on most winter, transitional, and summer ranges. The distribution of the various subspecies of big sagebrush generally reflects elevational difference as modified by edaphic factors. There are also some latitudinal differences in big sagebrush communities. West (1983a, 1983b) considered the more northern sagebrush vegetation as the sagebrush steppe, and the Great Basin and Colorado Plateau examples of the Great Basin sagebrush type. In the sagebrush steppe type there is potentially a more equal sharing of dominance between woody and herbaceous species. In the Great Basin sagebrush type the balance between woody and herbaceous species is much more precarious. The Lassen interstate mule deer herd occupy a transitional area between these designations, with the Modoc Plateau of northeastern California falling into the sagebrush steppe (Fig. 3).

There is cvidence the American bison (Bison bison) occurred on the Modoc Plateau in relatively recent times before contact with European man (Merrian 1926). This indicates the sagebrush vegetation of the Modoc Plateau was similar to the sagebrush steppe of eastern Oregon and Idaho rather than the Great Basin sagebrush type. The lower winter ranges in northwestern Nevada are within the Great Basin sagebrush type (Young et al. 1978b). 


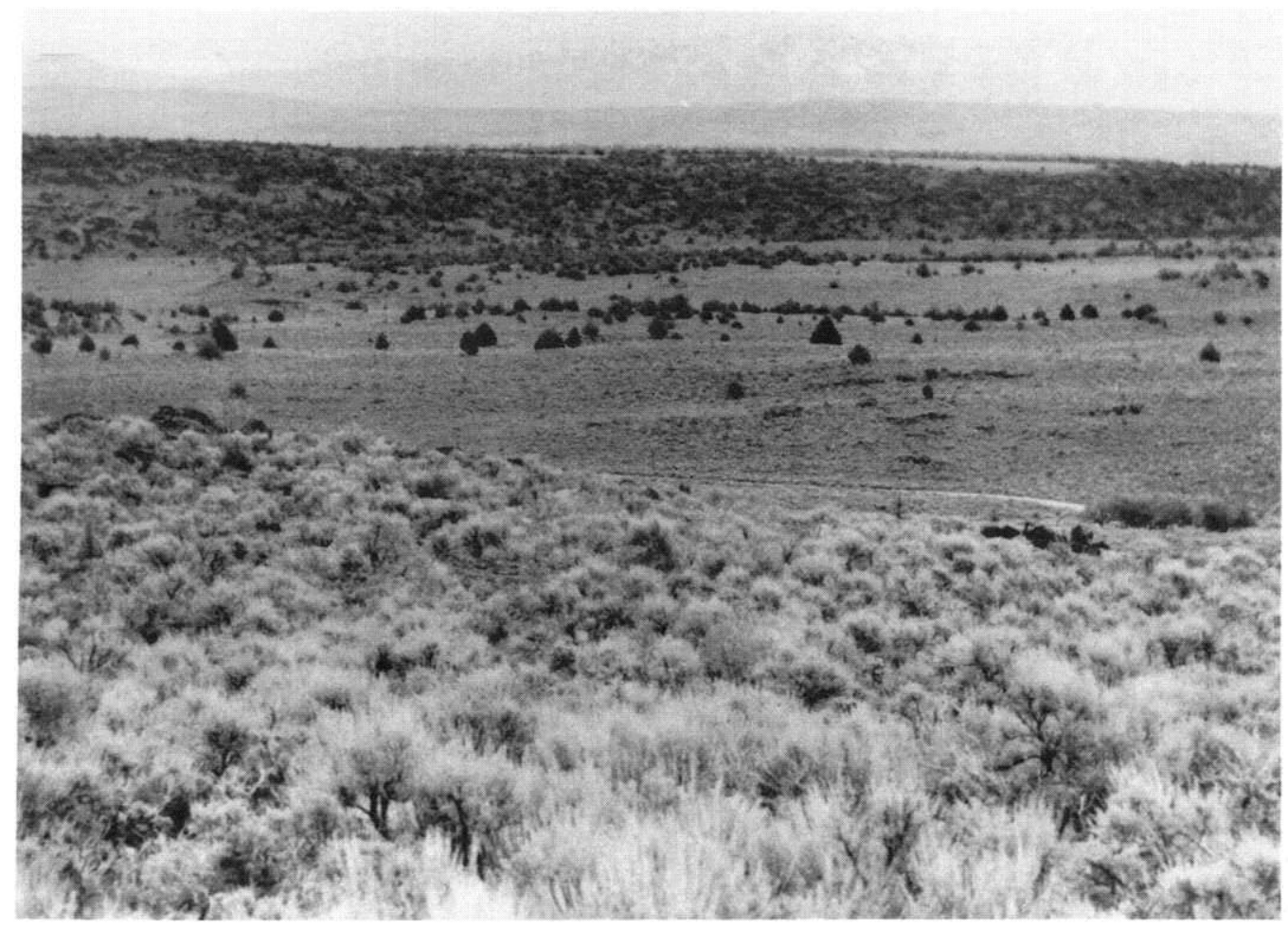

Fig. 3. Typical habitat for the East Lassen Interstate mule deer herd.

\section{Role of Shrubs in Pre-Contact Vegetation}

Virtually all western Great Basin plant communities that have sagebrush species $I_{\text {now }}$ had them under pre-contact conditions (Young et al. 1978a). Subtle changes in density of shrubs in sagebrush communities have significant impacts on the herbaceous vegetation and the converse is also true. This is illustrated by the research of Sneva (1972) that reported for every $1 \%$ increase in big sagebrush (Artemisia tridentata Nutt.) cover between 10 and $20 \%$ there was a $10 \%$ decrease in herbaceous productivity. For example, with $10 \%$ canopy cover of big sagebrush, herbaceous cover might be 100 units per $\mathrm{m}^{2}$. Increase the shrub cover to $15 \%$ and herbaceous production is reduced to 50 units per $\mathrm{m}^{2}$. At $20 \%$ shrub cover herbaceous production would approach zero. Casual observation of 10,15 , and $20 \%$ canopy cover of big sagebrush communities would reveal few differences in a silver-gray, shrub dominated landscape, but changes in this narrow range in canopy cover bring extreme influences to the sub-dominant herbaceous layer in the communities. Both the extensive review of Ellison (1960) and the life time studies of Daubeunire (1970) conclude that for most big sagebrush communities the dominance of shrubs increases with domestic livestock grazing and conversely tends to decrease with prolonged protection from such grazing, but shrubs never completely disappear from the communities.

\section{Preference for Sagebrush Browse}

During the last 2 decades research primarily conducted at the Shrub Science Laboratory, Provo, Ut., has shown that significant difference in the preference mule deer exhibit for big sagebrush browse exist among and within subspecies of big sagebrush (Welch and McArthur 1981, Welch et al. 1983). These issues are critical in interpreting the influence of variable preference for big sagebrush ecotypes by herbivores in the observed cycles in mule deer populations. Do domestic livestock and mule deer have the same or variable preference for the browse of big sagebrush ecotypes? Did the virtual unlimited seedling recruitment of big sagebrush in many plant communities during the 1890-1940 time period influence the frequency of mule deer preferred genotypes in big sagebrush populations? And, does the frequency of preferred ecotypes of big sagebrush differentially occur among subspecies and plant communities that compose mule deer seasonal habitat?

\section{Biological Processes Influencing Mule Deer Habitat}

The pre-contact vegetation of the area that currently supports the Lassen interstate mule deer herd was not composed of plant communities all in 1 stage of succession, even for communities located on sites of the same potential vegetation. The vegetation was composed of communities in various successional stages. Wildlife ecologists have long proposed that patchiness of habitat, providing an edge effect, was desirable compared to uniformity (Leopold 1950, Thomas et al. 1979, Maser and Thomas 1983). The relative uniformity of successional stages in vegetation composed of communities of similar potential depends on the frequency and extent of stand renewal processes.

\section{Wildfires}

In big sagebrush communities wildfires are the primary stand renewal process. Excessive grazing reduced grasses and brought about the reduction of fine fuels to carry wildfires (Julander 1962, Urness 1976, Gruell 1985). The shrubs then became larger, more 
vigorous, and established in higher densities (Dietz and Nagy 1976). This vegetation change was beneficial to mule deer herds throughout the West.

In little more than a century the sagebrush plant communities of the northwestern Great Basin have gone through periods of: 1) pristine wildfire frequency with aboriginal burning, 2) promiscuous burning, 3) attempted complete suppression of wildfires, and 4) attempts at prescribed burning and let-burn policies for wildfires (Young et al. 1972).

The lower elevation portions of the Great Basin give up evidence of past wildfire frequency very grudgingly. There are few if any trees that record fire scars, and sites to preserve subaerially deposited charcoal are rare. Generally, trees with long records of fire scars provide minimum estimates of the frequency of wildfires on the basis that if they were not somewhat protected from wildfires by soils and/or topographic features, they would not have survived to record repeated fires. Studies on the Modoc Plateau in Lassen County, on the western margin of the interstate mule deer range, revealed 28 fire scared western juniper (Juniperus occidentalis Hook.) trees in a 250 ha woodland (Young and Evans 1981). The fire scars grouped in the decades 1640 to $1650,1750-1760$, and 1830-1840. Each of these instances of wildfires probably represents 1 large fire. The variation in dates within the decade from which the fire was identified is probably due to false or missing rings on the various trees. Whisenant (1989) estimated the frequency of wildfire return in sagebrush vegetation averaging 60 to 110 years on the Snake River Plains of Idaho. Burkhardt and Tisdale (1976) estimated that pre-contact wildfires were much more frequent in the western juniper woodlands of southwestern Idaho. Henry Wright (1980), using the data of Young and Evans (1974), made the novel suggestion that the frequency of wildfire return in big sagebrush communities had to be longer than the interval of dominance of root sprouting sub-dominant shrubs such as rabbitbrush that are the woody natural secondary successional species in these communities following wildfires. Essentially if the frequency of wildfire was shorter than this interval there would have been no big sagebrush communities at contact time.

It has been popular in the past to strcss the importance of aboriginal burning in shaping pre-contact vegetation (e.g. Stewart 1963). Daubeunire (1970) considered such burning to be inconsequential in shaping the sagebrush steppe of the pre-contact vegetation of the Columbia Basin. In the western Great Basin, where we are concerned with the Lassen interstate mule deer herd, it is difficult to obtain an estimate of the importance of aboriginal burning. The Paiute Indians of Lassen County, Calif. historically used fire as a tool in hunting mule deer in the fall (Riddle 1978).

Considering the knowledge that has been developed of secondary succession in big sagebrush communities and the dynamics of relic communities it is apparent that the pristine vegetation of the sagebrush portion of the Lassen interstate mule deer herd must have consisted of a mosaic of communities in various stages of secondary succession. Recently burned areas would be solidly dominated by perennial grasses and broad-leaved species.

For a widespread landscape dominant, big sagebrush is atypical in that it does not have an active wind or granivore seed dispersal system, and it does not build persistent seedbanks (Young and Evans 1989). Against stiff competition from well established perennial grasses which were not injured by wildfires occurring in late summer, the only time the vegetation would burn, the re- establishment of big sagebrush must have been a very slow process. Currently the root sprouting sub-dominant shrubs persist in dominance for 10 to 15 years (Young and Evans 1974). Considering the slow rate of return of big sagebrush in fully stocked crested wheatgrass (Agropyron desertorum Fischer) stands (Frischknecht and Bleak 1957), the return to shrub dominance must have been very slow. The key in understanding precontact secondary succession perhaps lies in the balance of herbaceous and woody species that dampened the dynamics of change. The sagebrush/bunchgrass communities must have been in the 0 to $10 \%$ big sagebrush cover level for intervals of up to 50 years. The physical fire scar evidence from the western portion of the range of the Lassen interstate mule deer herd indicates that major fires that scarred more than 1 tree occurred at intervals of 80 to 110 years (Young and Evans 1981). If we use Whisenant's (1989) lower fire return frequency estimate of 60 years very little of the pre-contact big sagebrush vegetation was clearly in the total shrub domination stage.

Once established, big sagebrush plants have tremendous reproductive potential for the full potential century plus life of the plants (Young et al. 1989). In fully stocked big sagebrush stands the tremendous seed rain produces crops of sagebrush seedlings that essentially act as annuals, preempting soil moisture and limiting the establishment of seedlings of perennials. The sagebrush seedlings are not sufficiently pernicious to have marked establishment in fully stocked perennial grass stands (Blaisdell 1949). Big sagebrush seedling establishment must have been highly selective in the pre-contact environment. In terms of habitat for mule deer the important question is how preferred forms of big sagebrush fared in this selective seedbed environment? With limited big sagebrush recruitment, were the low populations of mule deer in pre-contact environments sufficient to suppress preferred forms of big sagebrush?

\section{Vegetation Reaction to Introduction of Domestic Livestock}

Livestock were introduced into the western Great Basin in the late 1860 s and numbers grew very rapidly during the 1870 s (Young and Sparks 1985). By the 1880s, rangelands located close to water supplies were often severely impacted by excessive grazing. The dominant shrubs were not preferred by cattle (Bos taurus), horses (Equus caballus), and to a lesser extent by sheep (Ovis aries). The dominant herbaceous species were perennial bunchgrasses that cannot be grazed year after year without rest during the growing season. The loss of the perennial grasses left a biological near vacuum in the understory that was exploited by sagebrush seedlings.

The winter of 1889-90 was extremely severe and resulted in death losses to cattle approaching $90 \%$ in northern Nevada (Young and Sparks 1985). There were also exceptional death losses among wildlife during this severe winter. The result was an over grazed herbaceous layer that was open for exploitation by woody plant seedlings without predation by domestic or wild herbivores. Also of benefit to these woody species were the extremely wet years that followed this severe winter as indicated by precipitation data collected in Susanville, Calif. that ranged from $79.65 \mathrm{~cm}$ to $142.80 \mathrm{~cm}$ in the period of 1889 to 1896 (Upchurch and Brown 1951). J.H. Robertson, Professor Emeritus at the University of Nevada Reno, age dated several excellent stands of antelope bitterbrush in northern Nevada that apparently established during the 1890s (personal communication 1994). 


\section{Establishment of Antelope Bitterbrush Stands}

Antelope bitterbrush undoubtedly played a significant role in plant communities in and adjacent to conifer woodlands under pre-contact conditions (Daubeunire 1970). It has long been noted that many of the most valuable antelope bitterbrush stands for wintering mule deer became established at lower elevations in the big sagebrush zone during the period from 1890 through 1910 (e.g. Hormay 1943). This was the period, as previously noted, after the extensive excessive grazing of perennial grasses and in the reduced herbivore era after the winter of 1889-90. The reaction of herdsmen to the visible encroachment of woody species was promiscuous burning. During a tour from Winnemucca, Nev. to Burns, Ore. in 1899, Griffiths (1902) reported the sky was clouded with smoke from promiscuous burning by shepherds in the foothills and mountains. The usual influence of burning on antelope bitterbrush plants is death, although under certain conditions and apparently with specific ecotypes of the shrub considerable post fire sprouting can occur (e.g. Blaisdell and Mueggler 1956). Antelope bitterbrush does enjoy a major advantage over big sagebrush in regards to destruction in wildfires. Antelope bitterbrush flowers in the spring and matures seeds in mid summer. These seeds dehisce and are largely collected by rodents and scatter hoard cached before the wildfire scason occurs (Nord 1965). Big sagebrush plants flower in the fall and mature seeds after the wildfire season. Big sagebrush seeds do not accumulate in seedbanks. If the sagebrush plants burn before flowering the entire reproductive potential of the shrub for the burned site is lost and a prolonged period of re-colonization is necessary. The caching of seeds of antelope bitterbrush largely occurs between shrubs away from shrub canopies and littcr accumulations. Sceds buried in the surface soil are usually safe from fire damage while the fuel associated with shrub canopies results in nearly complete sterilization of seedbeds (Young and Evans 1978). Antelope bitterbrush seed caches probably have reduced predation from rodents following wildfires because of reduced escape cover, limiting rodent activity. The seedlings also have reduced competition for soil moisture and nutrients because the big sagebrush is gone. The stands that established at the turn of the century also would have reduced predation from mule deer because of low post-contact populations.

\section{Modern Stand Renewal Processes}

\footnotetext{
Cheatgrass

Wildfires fueled by accumulations of the herbage and litter of the annual weeds cheatgrass (Bromus tectorum L.) and medusahead (Taeniatherum caput-meduase subsp. asperum L.) are the major stand renewal processes that influence the habitat of the Lassen interstate mule deer herd. Cheatgrass has revolutionized secondary succession in xeric site sagebrush plant communities in the entire Intermountain Area by providing a fine textured, early maturing fuel that increases the chance of ignition and rate of spread of wildfires. Whisenant (1989) estimated the presence of cheatgrass has reduced the interval between wildfires on the Snake River Plains from the previously reported 60 to 110 years to 5 years. Aldo Leopold (1949) recognized more than a half century ago how impossible it is to protect wildlife habitat from wildfire because of cheatgrass. Cheatgrass truncates secondary succession by largely inhibiting the establishment of perennial seedlings through competition for moisture (Robertson and
}

Pearce 1945, Evans et al. 1970, Young et al. 1987a, 1987b, Melgosa et al. 1990). Medusahead is a more recently introduced alien weed (Young 1992) that has replaced cheatgrass in specific sites in the western portion of the Lassen interstate mule deer herd range (Young and Young 1995). Medusahead is adapted to fine textured soils. It has become established in dwarf sagebrush communities [low sagebrush (Artemisia arbuscula Nutt.), Lahontan sagebrush (A. arbuscula subsp. longicaulis Nutt.), and black sagebrush ( $A$. nova Nelson)]. These dwarf sagebrush species are considered preferred browse by mule deer (Tueller 1979). The invasion of these sites by medusahead has brought wildfire back to these stands as a stand renewal process. These sites have been considered fire proof during modern times because of reduced herbaceous vegetation caused by past excessive grazing. Where western juniper trees grow on these sites they have been found with fire scars from pre-contact wildfires (Young and Evans 1981).

\section{Range Improvement}

During the 1960s there was a clear cut target to blame for the decline in mule deer numbers on range improvement practices, specifically the control of brush species with herbicides (e.g. Young et al. 1985) and the seeding of crested wheatgrass. In specific local instances such practices were probably detrimental to mule deer populations. During the summer of 1900 P.B. Kennedy and S.B. Doten (1901) described the range conditions north of Reno, Nev. as virtually being dust beds. It was in response to this type of range condition that the concept of range improvement was born. After an extended period of experimenting with native perennial grasses, without success, it was determined that the introduced perennial crested wheatgrass could be successfully seeded on sagebrush rangelands (Young and McKenzie 1982). Many current wildlife managers have expressed their deep displeasure with large crested wheatgrass seedings. This is understandable to a degree. Crested wheatgrass seedings took place over large areas of landscapes that resulted in large monocultures of crested wheatgrass ranges, decreasing browse in those areas. The success that this species exhibited was recognized resulting in the spraying, burning, and chaining of many less productive shrub communities to seed crested wheatgrass for the purpose of increasing livestock forage. This resulted in less browse for mule deer. Often though, wildfires occurred, and the seeding of crested wheatgrass was done to minimize the invasion of annual weeds such as cheatgrass. This was, and still is, a successful management tool in protecting arid landscapes from developing into fuel rich environments of annual grasslands. When large scale range improvement practices, including extensive crested wheatgrass seedings, were intelligently applied and objectively evaluated the results were found to be beneficial to mule deer populations (Heady and Bartolome 1977, Urness et al. 1983, Urness 1986). In evaluating the massive Vale, Ore. range improvement project Kindschy (1971) found a $25 \%$ increase in available browse on 22 transects that were sampled from 1963 through 1971 . He attributed this to excluding good browse stands from range improvement practices, seeding of browse species, and livestock management to limit late summer and fall use of browse species. The overall increase in the forage base from range improvement in the Vale project decreased competition between cattle and mule deer. The seeding of perennial grasses is critical to suppressing wildfires on rangelands. No other growth form of plants is as effective in biologically suppressing cheatgrass as perennial grasses. 
In the mid 1960s the public land management agencies became disillusioned with range improvement, apparently because of the capital requirements and the vocal perception of some wildlife managers and environmentalist that such practices were causing a decline in wildlife populations. Grazing management was substituted for active range improvement (Mosely 1994), but seldom applied as a prescription, specifically for improving wildlife habitat (Severson and Urness 1994).

\section{Grazing Management}

Observations in the northwestern Great Basin suggests that on mesic sites where native bunchgrasses still exist, grazing management systems often produced an increase in these herbaceous species. On drier sites at lower elevations few bunchgrasses remained, and seedling recruitment is limited by annual grass competition. Unfortunately for the Lassen interstate mule deer herd, neither the improved nor the degraded rangelands are particularly good mule deer habilat. The failure to recruit antelope bitterbrush seedlings in either high or low elevation habitat is particularly disturbing for mule deer.

The reality of the current situation is that removal of domestic livestock will dramatically exacerbate the difficulties of mule deer. The only tool land managers have to manage fuels on low elevation rangelands is the grazing animal (Mosley 1994, Severson and Urness 1994). The rest-rotation grazing systems that have been used were designed to favor the recruitment of perennial grass seedlings. In a situation with annual grass dominance, they result in accumulation of dangerous herbaceous fuel loads during periods of deferment or rest. This does not mean that some other grazing management system might not prove successful, especially in combination with intelligently designed and applied range improvement, including specific planting and grazing for wildfire suppression.

At higher elevation sites the elimination of grazing would accelerate the conversion of sites to near perennial grasslands, as they apparently were in pre-contact times.

\section{Wildfires in Perennial Grass Stands}

The Shinn Peaks area, largely in Lassen County, Calif., is a major upland portion of the central area of the Lassen interstate mule deer herd range. The lower flanks of the Shinn Peaks massif were covered with western juniper woodlands and badly degraded big sagebrush/bunchgrass communities in 1964 when a wind driven wildfire burned most of the mountain. The upper slopes of Shinn Peaks were mountain brush communities, typical of the Great Basin mountains with limited curlleaf mountain mahogany and quaking aspen (Populus tremuloides Michaux.) parklands. The wildfire burn area was broadcast seeded to a mixture of exotic perennial grasses. The burn was followed by a winter with deep, prolonged snow cover and excellent spring precipitation. Generally excellent stands of perennial grass were established. The area was lightly grazed following the 1964 burn and in 1990 the area burned again. The second wildfire burned in predominately perennial grass stands that were prematurely dry from exceptional drought. The native shrubs that had returned, including occasional excellent stands of antelope bitterbrush, were again destroyed. Much of the upper slopes of Shinn Peaks is now a perennial grassland dominated by native plants. Perhaps it rather closely resembles how the landscapes appeared before Europeans made contact with the area.

\section{Juniper Woodlands}

Perhaps the most dramatic change in the habitat of the Lassen interstate deer herd has been the replacement of antelope bitterbrush-mountain big sagebrush/perennial bunchgrass communities with dense western juniper woodlands (e.g. Young and Evans 1981). Beginning in the late 1800 s juniper woodlands began to encroach onto open shrub/grass sites, eventually forming closed stands of trees. On the western and northern portions of the habitat of the Lassen interstate mule deer herd range, this conversion from productive browse and forage to sterile closed stands of western juniper is very evident. The frequency of wildfires, as conditioned by fuel for ignition and spread of fires, influences the increase in western juniper woodlands (Burkhardt and Tisdale 1976, Budy and Young 1987) but this dramatic change in habitat potential may also be related to climate and/or atmospheric gas changes (e.g. Mayeux et al. 1994).

Prescribed burning can reduce western juniper dominance before stands close. Othcrwise the tree competition will remove the understory vegetation and the woodlands become virtually fire proof, except under extreme conditions where fire suppression is impossible. Some wildlife managers have vigorously opposed these prescribed burns because they threaten the few remaining antelope bitterbrush stands (e.g. Updike et al. 1990). This management approach results in the loss of productive mule deer habitat (Burkhardt and Tisdale 1976).

Senescent antelope bitterbrush lose vigor, and provide little browse. A. Starker Leopold (1959) recognized the problem caused by stand decadence in a report to the Nevada Department of Fish and Game. He recommended that to maintain high carrying capacities of mule deer, deliberate manipulation of plant succession must be implemented (Leopold 1950 and 1959). This is critical in providing the necessary habitat to maintain high mule deer populations (Burkhardt et al. 1982). Many antelope bitterbrush stands today are dominated by 60-100 year old bitterbrush plants. These old shrubs simply do not produce and provide the nutritional browse of the younger more vigorous bitterbrush plants (Burkhardt et al. 1982).

The growth and decline of mule deer numbers in the central Great Basin may in themselves be a result of the destruction of vast expanses of coniferous woodlands duing the 19th century to serve as mine props, fuel wond, and charcoal for smelting silver ores (Budy and Young 1987, Young and Budy 1987). The 20th century regeneration and eventual maturation of these woodlands undoubtedly contribute to the modern decline of mule deer populations.

\section{Identifying Critical Habitat Requirements}

Mule deer populations are declining and will continue to decline until their habitat requirements are met and maintained. Several questions arise. What habitat conditions are lacking? Are decreasing winter ranges, the condition of remaining winter ranges, and livestock grazing the cause of our declining mule deer herds in northeastern California and northwestern Nevada as Loft and Menke (1990) suggest? Mule deer require nutritional input and cover from all of their environments, and in turn all environments are critically important to mule deer biology. Therefore, summer and transitional ranges are as important as winter ranges. Certainly poor conditioned winter ranges negative- 
ly effect mule deer, but good condition summer and transition ranges are justifiably just as important. Mule deer have been collected on the winter range of the Lassen mule deer herd in March of 1986, December of 1987, and December of 1992 (personal communication Dobel 1995, field biologist, Nevada Division of Wildlife and personal communication Phillips 1995, range conservationist, USDI, BLM, retired). The deer collected in March of 1986 (sample $=6$ ) were in poor condition. The wildlife pathologist at that time reported that due to poor winter and spring forage, malnutrition appears to be a problem with the East Lassen deer herd. The deer collected in December of 1987 and 1992 (Sample $=16$ and 11 respectively) were in borderline poor/fair condition (Leach 1988). This would suggest that these deer are not entering the winter range in good condition, and therefore malnutrition is the case before they reach their wintering ranges.

The better body condition mule deer are at the start of winter, the better their chance of survival (Burkhardt et al. 1982). The seasonal mule deer diet varies from a growth promoting (high protein and phosphorus) diet in the spring, to a fattening (high carbohydrate, fat and energy) diet in the summer and fall. A maintenance (low protein and energy) diet occurs in the winter. The spring and early summer periods are the time of best feeding conditions for mule deer in much of their range. These ranges produce a good variety of plant species that provide higher nutrient content and are more palatable (Dietz and Nagy 1976).

The body condition of the East Lassen mule deer herd, suggests that these deer are entering the winter range in less than suitable condition to sustain minimal survival and improve fawn recruitment. A more in depth analysis of the Lassen interstate mule deer herd summer and transitional ranges is needed. This will help locate what vegetational characteristics important to mule deer on these ranges are lacking, and to identify why these deer are not in good to excellent body condition before they enter winter. To do this, a sufficient number of mule deer that occupy this winter range must be radio collared to identify exactly what deer herds depend on this area for their wintering grounds, and what summer and transitional ranges these deer are using.

The Doyle Wildlife Management Area, administered by the California Department of Fish and Game, has been free from livestock grazing since the early 1950 s. The major disturbance in this management area has been wildfires. The habitat that has burned is dominated by cheatgrass, and buckwheat (Eriogonum nudum Benth.), while the unburned habitat is dominated by antelope bitterbrush, big sagebrush, and cheatgrass (Clements 1994, Clements and Young 1996). The most recent fire occurred in 1985 , yet there is no sign that antelope bitterbrush is regenerating. The antelope bitterbrush in the unburned habitat is becoming old and decadent, and minimal regeneration is occurring. The Doyle Wildlife Management Area exhibits much of the same problems as other areas of the Lassen interstate mule deer winter ranges that are grazed by domestic livestock.

Antelope bitterbrush is a critical browse species for wintering Lassen interstate mule deer herds. Data from the Bureau of Land Management suggest that $60 \%$ of the bitterbrush browse in their test plots are utilized before livestock grazing occurred on the allotments (personal communication Phillips 1995, range conservationist, USDI, BLM, retired). The annual growth of antelope bitterbrush produced in this area can be consumed by mule deer without other grazing animals present (personal communication Farchon 1995, range conservationist, USDI, BLM).
Poor annual growth of antelope bitterbrush in this area was apparent when individual bitterbrush shrubs were protected from all ungulate herbivory since 1988 . These protected shrubs produced $5-6 \mathrm{~cm}$ of leader length annually. More vigorous antelope bitterbrush shrubs typically produce 3 times this amount of annual twig growth (personal observation). Perhaps stand decadence as suggested by Leopold (1959) and Burkhardt et al. (1982) is a significant factor in mule deer population declines.

The high densities of mule deer experienced in the late 1950 s and early 1960 s were a result of significant events that took place previously due to excessive livestock grazing and decreased frequency of fire that promoted shrubs that benefited mule deer. Wildlife managers cannot restore these large mule deer populations without active intervention in plant succession on the range. Passive management will only result in the further decline of our mule deer populations (Urness 1990).

Fire is a natural occurrence, and thus will eventually occur on various mule deer habitats. Increased attention into suppressing catastrophic wildfires proned to be invaded by cheatgrass or medusahead need to be addressed to minimize the amount of acreage that is negatively affected by these catastrophic fires. Sufficient funds should be set aside to minimize delays in rehabilitation efforts. Seeds should be purchased and seeded the first fall following the fire. If possible, these seedings should occur just before the first snowfall is expected, therefore a lesser amount of seeds are being consumed by rodents and birds. Also these seeds are placed into the environment before winter allowing the seeds to go through the necessary processes required to germinate the following spring. If the seeding is delayed, cheatgrass and other invader species get a head start over the desirable species that resource managers prefer to have at that site.

There has truly been a lot of research conducted concerning mule deer. This research, along with extensive field experience, provides resource managers with much information on managing their mule deer herds. So, why is there so much arguing at the discussion table? If our goal is to improve habitats and to turn around the continuing decline of our mule deer populations, then the approach of assessing the importance of all habitats must be done with the perspective of the past as well as the technology of the present.

\section{Literature Cited}

Anon. 1993. To Research California History. Noble's Trail. Fukawee Tribe. Susanville, Calif.

Austin, D.D. and P.J. Urness. 1985. Values of four communities for mule deer on ranges with limited summer habitat. J. Range Manage. 38:167-171.

Beetle, A. 1960. The study of sagebrush: the section Tridentata complex. Bull. 368. Wyoming Agr. Exp. Sta., Univ. Wyoming, Laramie, Wyo.

Billings, W.D. 1949. The shadscale vegetation zone of Nevada and eastern California in relation to climate and soils. Amer. Midland Nat. 42:87-107.

Bissell, H.D. and H. Strong. 1955. The crude protein variations in the browse diet of California deer. California Fish and Game 41:145-155.

Blaisdell, J.P. 1949. Competition between sagebrush scedlings and reseeded grasses. Ecol. 37:365-370.

Blaisdell, J.P. and W.F. Muegler. 1956. Sprouting of bitterbrush (Purshia tridentata) following top removal. Ecol. 37:145-155.

Budy, J.D. and J.A. Young. 1987. Energy crisis in the 19th century in the Great Basin woodlands. pp. 23-30. In: R.L. Everett (ed.) Proc. Pinyon-Juniper Conference. Gen Tech. Rep. 215, IJSDA, Forest Service, Ogden, Ut. 
Burkhardt, J.W. and E.W. Tisdale. 1976. Causes of juniper invasion in southwestern Idaho. Ecol. 57:472-484.

Burkhardt, J.W., D.A. Klebenow, E. Smith, and R. Beall. 1982. Mule deer in the Sheldon National Wildlife Refuge. Final report for the U.S. Fish and Wildlife Service Contract No. 14-16-00178086. pp. 99. Reno, Nev.

Clements, C.D. 1994. Influence of rodent predation on antelope bitterbrush seeds and seedlings. Thesis. Univer. Nevada Reno. pp. 49. Reno, Nev.

Clements, C.D. and J.A. Young. 1996. Influence of rodent predation on antelope bitterbrush seedlings. J. Range Manage. 49:31 34.

Clements, F.E. and E.S. Clements. 1939. The sagebrush declimax. Carnegie Inst., Washington Yearbook. 38:139-140.

Daubeunire, R. 1970. Steppe vegetation of Washington. Bull. 62. Washington Agr. Exp. Sta., Pullman, Wash.

Denny, R.N. 1976. Regulations and mule deer harvest-political and biological management. pp. 87-92. In: Proc., Mule Deer Decline in the West. Utah State Univ., Logan, Ut.

Dietz, D.R. and J.G. Nagy. 1976. Mule deer nutrition and plant utilization. pp. 71-78. In: Proc., Mule Deer Decline in the West. Utah State Univ., Logan, Ut.

Ellison, L. 1960. Influence of grazing on plant succession of rangelands. Bot. Rev. 26:1-78.

Evans, R.A., H.R. Hobo, R.E. Eckert, Jr., and J.A. Young. 1970. Functional environment of downy brome communities in relation to weed control and revegetation. Weed Sci. 18:154-162.

Frischnecht, N.C. and T.A. Bleak. 1957. Encroachment of big sagebrush on seeded range in northern Nevada. J. Range Manage. 10:165-170.

Griffiths, D. 1902. Forage conditions on the northern border of the Great Basin. Bull. 15. USDA, Bureau of Plant Industry, GPO, Washington, D.C.

Gruell, G.E. 1985. Fire on the carly western landscapc. Northwest Sci. 59:97-107.

Gruell, G.E. 1986. Post-1900 mule deer irruptions in the Intermountain west: Principle cause and influence. pp. 1-37. In: Gen. Tech. Rep. INT 206. USDA, Forest Service, Ogden, Ut.

Heady, H.F. and J. Bartolme. 1977. The Vale rangeland program: the desert repaired in southeastern Oregon. Resource Bull. 70, USDA, Forest Service, Portland, Ore.

Helfrich, D., E. Helfrich, and T. Hunt. 1984. Emigrant Trails West. Trails West Inc., Reno, Nev.

Hormay, A.L. 1943. Bitterbrush in California. Res. Note 39. USDA, Forcst Service, Bcrkeley, Calif.

Julander, O. 1955. Deer and cattle range relations in Utah. Forest Sci. $1: 130-139$

Julander, O. 1962. Range management in relation to mule deer habitat and herd productivity. J, Range Manage. 15:278-281.

Julander, O. and J.B. Low. 1976. A historic account and present status of mule deer in the west. pp. 3-20. In: Proc., Mule Deer Decline in the West. Utah State Univ., Logan, Ut.

Kennedy, P.B. and S.B. Doten. 1901. A preliminary report on the summer ranges of western Nevada sheep. Bull, 55. Nev. Agr. Exp. Sta., Reno, Nev.

Kindschy, R.R. 1971. The Vale project and wildlife ecology. USDI, Bureau of Land Management, Vale, Ore.

Lassen, R.W., C.M. Ferrel, and H. Leach. 1952. Food habits, productivity and condition of the Doyle mule deer herd. California Fish and Game. 38:211-224.

Leach, H.R. 1956. Food habits of the Great Basin deer herd of California. California Fish and Game. 42:243-308.

Leach, H.R. 1988. Food items eaten by 16 Rocky Mountain mule deer, Buffalo Creek area, Washoe Co., Nev. California Dep. Fish and Game Reno, Nev.

Leckenby, D.A., D.P. Sheehy, C.H. Nellis, R.J. Scherzinger, I.D. Luman, W. Elmore, J.C. Lemos, L. Doughty, and C.E. Trainer. 1982. Mule deer. pp. 40. In: Wildlife habitats in managed rangelands-The Great Basin of southeastern Oregon. Gen. Tech. Rep. 139, USDA, Forest Service, Portland, Ore.

Leopold, A.S. 1949. A Sand County Almanac. Oxford University Press, New York, N.Y.
Leopold, A.S. 1950. Deer in relation to plant succession. Trans. N. Amer. Wildl. Conf. 15:571-580.

Leopold, A.S. 1959. In Survey of Fish and Game problem in Nevada. Nevada Legislative Counsel Bur. Bull. \#36. Carson City, Nev.

Leopold, A., L.K. Sowle, and D.L. Spencer. 1947. A survey of overpopulated deer ranges in the United States. J. of Wildlife Manage. 11:162-177.

Loft, E.R. and J.W. Menke. 1990. Evaluations of fire effects on mule deer habitats in Lassen County. California Dep. Fish and Game. Hill Bill Contract No. FG1C-2090.

Maser, C. and J.W. Thomas. 1983. Wildlife habitats in managed rangelands-The Great Basin of southeastern Oregon. pp.15. In: Gen. Tech. Rpt. 160. USDA, Forest Service, Portland, Ore.

Mayeux, H.S., H.B. Johnson, and H.W. Polly. 1994. Potential interactions between global change and Intermountain annual grasslands. pp. 95-100. In: S.B. Monsen and S.G. Kitchen (ed.) Proc. Ecology and Management of Annual ranges. Gen. Tech. Rep. 313, USDA, Forest Service, Ogden, Ut.

McArther, E.D. and A.P. Plummer. 1978. Biogeography and management of native western: A case study: section Tridentatae of Artemisia. Great Basin Naturalist Mem. 2:229-243.

Melgosa, A.G., R.S. Nowak, and R.J. Tousch. 1990. Soil water expliotation after fire: Competition between Bromus tectorum (cheatgrass) and two native species. Oecologia 83:7-13.

Merrian, C.H. 1926. The buffalo of northeastern California. J. Mammology 7:211-214.

Mosley, J.C. 1994. Prescribed sheep grazing to enhance wildlife habitat on North America rangelands. pp. 18-56. In: The role of sheep grazing in natural resource management. SID Sheep Res. J. Spec. Issue.

Nord, F.C. 1965. Autecology of bitterbrush in California. Ecol. Monogr. 35:307-334.

Riddle, F.A. 1978. Honey Lake Paiute Ethnography. Nevada State Museum Occasional Papers No. 3. pp. 1-116. Carson City, Nev.

Robertson, J.H. and C.K. Pearce. 1945. Artificial reseeding and closed communities. Northwest Sci. 19:58-66.

Severson, K.E. and P.J. Urness. 1994. Livestock grazing: A tool to improve wildlife habitat. pp. 232-249. In: Ecological Implications of Livestock Herbivory in the West. Soc. for Range Manage. Denver, Colo.

Stewart, O.C. 1963. Barriers to understanding the influence of the use of fire by aboriginies on vegetation. Proc. 2nd Tall Timber Fire Fcolngy Conf. Tallahassee, Fla. pp. 117-126.

Sneva, F.A. 1972. Grazing return following sagebrush control in eastern Oregon. J. Range Managc. 25:174-178.

Thomas, J.W., C. Maser, and J.E. Rodiek. 1979. Edges. pp. 48-59. In: J.W. Thomas (ed.) Wildlife Habitats in Managed Forests of the Blue Mountains of Oregon and Washington. Agriculture Handbook No. 553, Forest and Range Expt. Sta., USDA, Forest Service, Portland, Ore.

Tueller, P.T. 1979. Food habits and nutrition of mule deer on Nevada ranges. Federal Aid in Wildlife Restoration Project W-48-5, Study 1, Job 2, University of Nevada Reno, Reno, Nev.

Upchurch, M.L. and T.S. Brown. 1951. Land, livestock, and deer in the Milford-Doyle area of northeastern California. California Agr. Exp. Sta., Berkeley, Calif.

Updike, D.R., E.R. Loft, and F.A. Hall. 1990. Wildfires on big sagebrush/antelope bitterbrush range in northeastern California: Implications for deer populations. pp. $41-46 . \ln$ : S.B. Monsen and S.G. Kitchen (ed.) Proc. Ecology and Management of Annual Rangelands. Gen. Tech. Rep. 313, USDA, Forest Service, Ogden, Ut.

Urness, P.J. 1976. Mule deer habitat changes resulting from livestock practices. pp. 21-35. In: Proc. Mule Deer Decline in the West. Utah State Univ., Logan, Ut.

Urness, P.J. 1986. Value of crested wheatgrass for big game. pp. 147. 153. In: K. L. Johnson (ed.) Crested Wheatgrass. Utah State Univ. Logan, Ut.

Urness, P.J. 1990. Livestock as manipulators of mule deer winter habitat in northern Utah. pp. 25-40. In: K.E. Severson (ed.) can livestock be used as a tool to enhance wildlife habitat? Soc. Range Manage. Symp., Gen. Tech. Rpt. RM-194. USDA, Forest Service, Fort Collins, Colo. 
Urness, P.J., D.D. Austin, and L.C. Fierro. 1983. Nutritive value of crested wheatgrass for wintering mule deer. J. Range Manage. 36:225-226.

Welch, B.L. and E.D. McArthur. 1981. Variations of monoterpenoid content among subspecies and accessions of Artemisia tridentata grown in uniform gardens. J. Range Manage. 34:380-384.

Welch, B.L., E.D. McArthur, and J.N. Davis. 1983. Mule deer preference and monoterpenoids (essential oils). J. Range Manage. 36:485-487.

West, N.E. 1983a. Great Basin-Colorado Plateau sagebrush semi-desert. pp. 331-349. In: N.E. West (ed.) Temperate Desert and Semi-Deserts. Vol. 5. Ecosystems of the World. Elsevier, Amsterdam, Netherlands.

West, N.E. 1983b. Western Intermountain steppe. pp. 351-374. In: N.E. West (ed.) Temperate Desert and Semi-Deserts. Vol. 5. Ecosystems of the World. Elsevier, Amsterdam, Netherlands.

Whisenant, S.G. 1989. Changing fire frequencies on Idaho's Snake River Plains: ecological management implications. pp. 4-10. In: E.D. McArthur, E.M. Romney, S.D. Smith, and P.T. Tueller (ed.) ProcSym. On Cheatgrass Invasion, Shrub Die-Off, and other Aspects of Shrub Biology and Management. Gen. Tech. Rep. 276. USDA, Forest Service, Ogden, Ut.

Work, John. 1833. The journal of John Work. Fur Brigade to the Boneventura. California Expedition 1832-1833 for the Hudson Bay Company. Edited by Alice Maloney and Herbert Eugene Bolten. California Historical Society, San Fransisco, Calif.

Wright, H.A. 1980. The role and use of fire in the semi-desert grassland type. In: Gen. Tech. Rpt. 85. USDA, Forest Service, Ogden, Ut.

Young, J.A. 1992. Ecolgy and management of medusahead (Taeniatherum caput-medusa ssp. asperum (Simk.) Melderis). Great Basin Naturalist 52(3):245-252.
Young, J.A. and J.D. Budy. 1987. Adaptation of track laying tractors for forest road and trail construction. J. Range Manage. 31(3)122-132.

Young, J.A. and R.A. Evans. 1974. Population dynamics of green rabbitbrush in disturbed sagebrush communities. J. Range Manage. 27:127-132.

Young, J.A. and R.A. Evans. 1978. Population dynamics after wildtires in sagebrush grasslands. J. Range Manage. 31:283-289.

Young, J.A. and R.A. Evans. 1981. Demography and fire history of a western juniper stand. J. Range Manage. 34:501-506.

Young, J.A. and R.A. Evans. 1989. Dispersal and germination of big sagebrush (Artemisia tridentata) seeds. Weed Sci. 37:319-325.

Young, J.A. and D. McKenzie. 1982. Rangeland drill. Rangelands 4:108-113.

Young, J.A. and B.A. Sparks. 1985. Cattle in the Cold Desert. Utah State Univ. Press, Logan, Ut.

Young, J.A. and C.G. Young. 1995. Medusahead research in the western Great Basin. Great Basin Revegetation Notes 2(1):1-24.

Young, J.A., R.E. Eckert, Jr., and R.A. Evans. 1978a. Historical perspective regarding the sagebrush ecosystem. pp. 1-13. In: Proc. The Sagebrush Ecosystem. Utah State Univ., Logan, Ut.

Young, J.A., R.A. Evans, and J. Major. 1972. Alien plants in the Great Basin. J. Range Manage. 25:194-201.

Young, J.A., R.A. Evans, and J. Major. 1978b. Sagebrush steppe. pp. 763-796. In: M.G. Barbour and J. Major (ed.) Terrestrial Vegetation of California. Wiley, New York, N.Y.

Young, J.A., R.A. Evans, and D.E. Palmquist. 1989. Big sagebrush (Artemisia tridentata) seed production. Weed Sci. 37:47-53.

Young, J.A., R.A. Evans, and D. McKenzie. 1985. History of brush control on western rangelands. Texas Tech Press, Lubbock, Tex.

Young, J.A., R.A. Evans, R.E. Eckert, Jr., and B.L. Kay. 1987. Cheatgrass. Rangelands. 9:266-270. 